\title{
Valorization of organic waste with simultaneous biogas upgrading for the production of succinic acid
}

Babaei, Mahsa; Tsapekos, Panagiotis; Alvarado-Morales, Merlin; Hosseini, Maryam; Ebrahimi, Sirous; Niaei, Aligholi; Angelidaki, Irini

Published in:

Biochemical Engineering Journal

Link to article, DOI:

10.1016/j.bej.2019.04.012

Publication date:

2019

Document Version

Peer reviewed version

Link back to DTU Orbit

Citation (APA):

Babaei, M., Tsapekos, P., Alvarado-Morales, M., Hosseini, M., Ebrahimi, S., Niaei, A., \& Angelidaki, I. (2019). Valorization of organic waste with simultaneous biogas upgrading for the production of succinic acid.

Biochemical Engineering Journal, 147, 136-145. https://doi.org/10.1016/j.bej.2019.04.012

\section{General rights}

Copyright and moral rights for the publications made accessible in the public portal are retained by the authors and/or other copyright owners and it is a condition of accessing publications that users recognise and abide by the legal requirements associated with these rights.

- Users may download and print one copy of any publication from the public portal for the purpose of private study or research.

- You may not further distribute the material or use it for any profit-making activity or commercial gain

- You may freely distribute the URL identifying the publication in the public portal 


\title{
Valorization of organic waste with simultaneous biogas upgrading for
}

\section{the production of succinic acid}

Mahsa Babaei ${ }^{a}$, Panagiotis Tsapekos ${ }^{b}$, Merlin Alvarado-Morales $^{b}$, Maryam Hosseini $^{c *}$, Sirous Ebrahimi $^{\mathrm{d}}$, Aligholi Niaei ${ }^{\mathrm{a}}$, Irini Angelidaki ${ }^{\mathrm{b} *}$

a. Department of Chemical \& Petroleum Engineering, University of Tabriz, Tabriz, Iran

b. Technical University of Denmark, Department of Environmental Engineering, Building 113, DK-2800 Kgs. Lyngby, Denmark

c. Department of Chemical Engineering, Faculty of Engineering, Azarbaijan Shahid Madani University, Tabriz, Iran

d. Biotechnology Research Center, Faculty of Chemical Engineering, Sahand University of Technology, Tabriz, Iran

\begin{abstract}
* Corresponding Authors:

Maryam Hosseini (m.hosseini@azaruniv.ac.ir)

Irini Angelidaki (iria@env.dtu.dk)
\end{abstract}

Increased awareness on environmental drawbacks of petroleum-based industries are promoting transition from fossil-based succinic acid to its bio-based alternative. However, due to low price of oil the economic feasibility of the bio-succinic acid production is still challenged. The current study focuses on valorization of organic fraction of household kitchen waste pretreated by enzymatic hydrolysis to produce succinic acid with process $\mathrm{CO}_{2}$ supply from biogas. The total sugar content of $119.3 \pm 1.7 \mathrm{~g} / \mathrm{L}$ with $15 \%$ xylose and $85 \%$ glucose was obtained by enzymatic hydrolysis. Moreover, based on substrate inhibition tests with glucose, lower glucose concentration is to be more efficient in terms of succinic acid yield and production rate. Through fermentation of hydrolysate (17 g/L sugar) with Basfia succiniciproducens succinic acid was produced in $0.46 \pm 0.0$ and $0.25 \pm 0.0 \mathrm{gSA}_{\mathrm{S}} / \mathrm{g}_{\text {glucose, }}$ using magnesium carbonate and raw biogas, respectively. 
Batch fermentation in the bioreactor with raw biogas resulted in glucose consumption rate of $2.22 \pm 0.25$ $\mathrm{g}_{\mathrm{Glu}} / \mathrm{g}_{\mathrm{DCw}} \cdot \mathrm{h}$, and $8.0 \%(\mathrm{v} / \mathrm{v})$ of $\mathrm{CO}_{2}$ consumption in biogas. This study shows a proof of concept of organic waste valorization and raw biogas application in succinic acid production.

Keywords: Biogas upgrading; Enzymatic hydrolysis; Organic waste; Succinic acid

\section{Introduction}

Succinic acid (SA) is the building block that is used to make a wide range of products, mainly 1,4-butanediol (BDO), polybutylene succinate (PBS), polybutylenes. Increasing demand for BDO together with growing applications of SA in lubricants, pigments, food and pharmaceutical industries will drive the market for this product up to boost in near future [1]. From 2012, the shift from petroleum-based SA production to biobased alternative has been growing due to the global awareness on benefits of sustainable procedures and hazards of carbon footprints. In the bio-based route, bacteria such as Actinobacillus succinogenes $130 z$, Mannheimia succiniciproducens, Basfia succiniciproducens and Anaerobiospirillum succiniciproducens are converting sugars along with carbon dioxide to bio-succinic acid. Therefore in the bio-based route, besides the production of the useful product, carbon dioxide is captured, contributing to environmental advantages. Moreover, as substrate cost counts for more than $40 \%$ of total costs of bioprocesses it would be advantageous to provide the sugars from cheap waste streams which would contribute to the economic feasibility and add to the environmental advantages of the process [2].

The recent years increased attention has been paid on technologies for valorization of wastes [3]. Along this line, the organic fraction of household kitchen waste (OFHKW), can be a potential useful resource for production of high value compounds. It has been estimated that $1 / 3$ to $1 / 2$ of the annual food produced worldwide is not consumed $[4,5]$ and is disposed as organic waste, with 88 million tons of food waste generated in Europe in 2016 [6]. The organic fraction of municipal waste is mainly treated in three ways, incineration, anaerobic digestion or composting [7]. However, it is more of economic interest to integrate 
resource management with its valorization in ways such as production of chemicals as fatty acids [8], biopolymers [9], lactic acid [10] and succinic acid [11].

The source separated OFHKW, composed mainly of disposed food residues, is a rich source of degradable carbohydrates and essential nutrients [12]. It is high in fermentable sugars as glucose and xylose, with total sugar and protein contents in the range of $35.5-69 \% \mathrm{w} / \mathrm{w}$ and $3.9-21.9 \% \mathrm{w} / \mathrm{w}$, respectively [13]. The dominant bacteria in household waste are lactic acid bacteria $[14,15]$. On the other hand, as all natural succinic acid-producing microorganisms were isolated from rumen fluids [16] the production of succinic acid using indigenous bacteria isolated from OFHKW is not practical. However, the possibility of producing SA from ruminal bacteria and food waste has been previously reported [17]. Integrating the SA production process with other value-added procedures such as biogas upgrading is appealing in terms of economics. The proof of concept was successfully studied previously by producing $14.4 \mathrm{~g} / \mathrm{L} \mathrm{SA}$ with a yield of $0.635 \mathrm{~g} / \mathrm{g}$ of pure glucose together with $35.4 \%(\mathrm{v} / \mathrm{v})$ increase in methane content after $24 \mathrm{~h}$ of fermentation using $A$. succinogenes $130 z$ [18]. Besides $A$. succinogenes 130z, the capnophilic gram negative bacteria $B$. succiniciproducens has also gained attention due to its performance on SA production from renewable sources [19]. B. succiniciproducens is characterized as non-pathogenic and facultative anaerobe [20] which utilizes both the reductive and oxidative TCA cycle branches to secrete succinic acid, potentially better production than $A$. succinogenes $130 z$, which only produces succinic acid via the reductive branch of the TCA cycle. Furthermore, of the other succinogenic bacteria, A. succiniciproducens is an opportunist pathogen and strictly anaerobic [21], and M. succiniciproducens, apart from not having a clear classification in terms of pathogenicity, exhibits a high number of auxotrophies [22]. Limited to quite a few studies on B. succiniciproducens, there is still not systematic investigation based on real organic fraction of household and biogas as feedstock. Moreover, systematic evaluation of the two most promising capnophilic bacteria at real conditions, which could evaluate both their process efficiency and also, their 
tolerance to real waste-feedstock is still lacking. This could provide important information, which would move this interesting technology ahead.

Hence, the aim of current work is directed to expand the integrated process of SA production and biogas upgrading. This is done by utilizing OFHKW as the substrate, pretreated by enzymatic hydrolysis to provide fermentable sugars, mainly glucose. Besides the commonly used $A$. succinogenes $130 z$, other promising bacteria $B$. succiniciproducens is also investigated on SA producing using OFHKW hydrolysate. As the fermentation process is performed in batch mode, glucose inhibitory levels were investigated through substrate inhibition tests on B. succiniciproducens. Finally, simultaneous SA production and biogas upgrading is performed using raw biogas from an anaerobic digestion plant as a proof of concept in upscaled fermentation using OFHKW hydrolysate.

\section{Materials and methods}

\subsection{Chemicals, bacterial strains and culture media}

All chemicals and enzymes in the current study were in analytical grade and purchased from Sigma Aldrich (Brøndby, Denmark). B. succiniciproducens (DSM 22022) and A. succinogenes 130z (DSM 22257) were provided from German Collection of Microorganisms and Cell Cultures (DSMZ, Germany). The pellet of freeze-dried ampoules of bacterium was rehydrated in Nutrient Broth (Sigma-Aldrich) and cultured in Columbia agar supplemented with $5 \%$ sheep blood (Bio-Rad, Denmark) at $37^{\circ} \mathrm{C}$ under aerobic condition with $5 \% \mathrm{CO}_{2}$ for $48 \mathrm{~h}$. The harvested cells were aseptically transferred into $10 \mathrm{~mL}$ tubes containing Tryptic Soy Broth (TSB) with $0.75 \% \mathrm{w} / \mathrm{v}$ glucose (Sigma-Aldrich). The tubes were flushed with pure $\mathrm{CO}_{2}$ gas after inoculation, sealed with rubber stoppers and incubated at $37^{\circ} \mathrm{C}$ for $48 \mathrm{~h}$ [18].

\subsection{Handling of organic fraction of household kitchen waste (OFHKW)}

The substrate used in this study originated directly from bio-waste bins locally provided in the municipality of Copenhagen [23], was kept at $-18{ }^{\circ} \mathrm{C}$ to prevent decomposition. The OFHKW was mainly consisted of 
food waste, with other organic materials such as flowers, used paper towels and kitchen rolls. In order to get homogenized composition, the OFHKW was first freeze-dried and then blended in a kitchen food processor to fine powder form and was stored at $4{ }^{\circ} \mathrm{C}$ before usage.

\subsection{Enzymatic hydrolysis}

In order to break down OFHKW to monomeric fermentable sugars for succinogenic bacteria; enzymatic hydrolysis was followed. The OFHKW was hydrolyzed using Celluclast $1.5 \mathrm{~L}^{\circledR}$ (EC 3.2.1.4, activity $\geq 700$ units/g) from Trichoderma reesei catalyzing the breakdown of cellulose, and cellobiase (EC 3.2.1.21, activity $\geq 750$ units/g) from Aspergillus niger (Novozyme $188^{\circledR}$, Denmark) catalyzing the hydrolysis of $\alpha-1,4$ linkages. Cellobiase was supplemented to Celluclast $1.5 \mathrm{~L}^{\circledR}$ to reduce the accumulation of cellobiose, which has an inhibitive enzymatic feedback on Celluclast $1.5 L^{\circledR}$ [24]. In order to find out the appropriate values of OFHKW and enzyme loadings, multiple hydrolysis tests were conducted. Specifically, $50 \mathrm{~mL}$ falcon tubes were filled with $30 \mathrm{~mL}$ of citric acid buffer $(0.5 \mathrm{mM}) \mathrm{pH}=4.8$ solution together with four different substrate loadings of $5,10,15$, and $20 \%(\mathrm{w} / \mathrm{v})$ and with three different Celluclast $1.5 \mathrm{~L}^{\circledR}$ loadings of 20,40 and 50 $\mathrm{U} / \mathrm{g}_{\mathrm{DM}}$ (DM: dry mass). The enzymatic loading of cellobiase was kept constant in all experiments at 10 $\mathrm{U} / \mathrm{g}_{\mathrm{DM}}$. After preparation, the tubes were incubated at $50^{\circ} \mathrm{C}$ with shaking at $150 \mathrm{rpm}$ for $24 \mathrm{~h}$. Samples were taken every $4 \mathrm{~h}$ and analyzed for sugar determination. Subsequently, the hydrolysis of OFHKW was carried out under the optimum conditions in replicate bioreactors (Sartorius BIOSTAT Aplus, Germany) with working volume of $1.5 \mathrm{~L}$ at controlled temperature of $50^{\circ} \mathrm{C}$ and $\mathrm{pH}$ at 4.8 to get the sufficient amount of hydrolysate for succinic acid production tests. Finally, the hydrolysate was sterilized by membrane filtration $(0.22 \mu \mathrm{m})$ and kept at $4^{\circ} \mathrm{C}$ before used.

\subsection{Seed culture}

The seed cultures for both the microorganisms were prepared in $50 \mathrm{~mL}$ sealed serum bottles containing 30 $\mathrm{mL}$ of subsequent media. The seed media for B. succiniciproducens contained (per liter) $10 \mathrm{~g}$ glucose, $5 \mathrm{~g}$ yeast extract, $5 \mathrm{~g}$ peptone, $1 \mathrm{~g} \mathrm{NaCl}, 0.2 \mathrm{~g} \mathrm{MgCl}_{2} \cdot 6 \mathrm{H}_{2} \mathrm{O}, 0.2 \mathrm{~g} \mathrm{CaCl}_{2} .2 \mathrm{H}_{2} \mathrm{O}, 3 \mathrm{~g} \mathrm{~K}_{2} \mathrm{HPO}_{4}, 1 \mathrm{~g}\left(\mathrm{NH}_{4}\right)_{2} \mathrm{SO}_{4}, 10 \mathrm{~g}$ 
$\mathrm{MgCO}_{3}[25]$. The seed media for $A$. succinogenes $130 \mathrm{z}$ consisted of (per liter) $10 \mathrm{~g}$ glucose, $5 \mathrm{~g}$ yeast extract, $10 \mathrm{~g} \mathrm{NaHCO}_{3}, 9.6 \mathrm{~g} \mathrm{NaHPO}_{4} .2 \mathrm{H}_{2} \mathrm{O}$, and $20.3 \mathrm{~g} \mathrm{~K}_{2} \mathrm{HPO}_{4} .3 \mathrm{H}_{2} \mathrm{O}$ [18]. The bottles containing seed media were sealed with rubber stoppers and crimped with aluminum caps, autoclaved at $121^{\circ} \mathrm{C}$ for $15 \mathrm{~min}$, flushed with pure $\mathrm{CO}_{2}$ and inoculated with $0.5 \mathrm{~mL}$ of $-80^{\circ} \mathrm{C}$ glycerol stock culture. Then, the bottles were incubated at $37^{\circ} \mathrm{C}$ until $\mathrm{OD}_{660}$ of 0.4 was reached.

\subsection{Fermentation in serum bottles}

The initial fermentation experiments were conducted in $250 \mathrm{~mL}$ sealed serum bottles containing $100 \mathrm{~mL}$ of strain specified medium for B. succiniciproducens [26] and $A$. succinogenes $130 z$ [18]. To these fermentation tests, organic carbon source and $\mathrm{MgCO}_{3}$ were added in equivalent concentrations in the range of $5-100 \mathrm{~g} / \mathrm{L}$, unless otherwise stated. The $\mathrm{pH}$ of the medium was adjusted to $6.7 \pm 0.1 \mathrm{using} 50 \% \mathrm{v} / \mathrm{v}$ phosphoric acid, and sterilized without carbon source at $121^{\circ} \mathrm{C}$ for $15 \mathrm{~min}$. Sterilized substrate (i.e. glucose or hydrolysate) was afterwards added in the media. In glucose inhibition tests of B. succiniciproducens, sterilized glucose was added in the range of 5-100 g/L. The bottles were then flushed with $\mathrm{N}_{2} / \mathrm{CO}_{2}(80 / 20$ vol\%) and inoculated with $5 \%(\mathrm{v} / \mathrm{v})$ exponentially growing seed culture with optical density (OD) of 0.4 at $660 \mathrm{~nm}$. Fermentations were run in duplicate at $37^{\circ} \mathrm{C}$ and $150 \mathrm{rpm}$. Samples $(\sim 1 \mathrm{~mL})$ were taken aseptically during the time course of fermentation to monitor bacterial growth, sugar consumption and fermentation products.

\subsection{Fermentation in bioreactor and biogas upgrading}

Fermentation of hydrolysate was carried out in two identical $3 \mathrm{~L}$ bioreactors (Sartorius BIOSTAT Aplus, Germany) with working volume of $1.5 \mathrm{~L}$. The system setup used has been detailed described before [18]. A pilot biogas reactor with a working volume of $500 \mathrm{~L}$ provided the raw biogas. The anaerobic reactor was fed with source separated municipal organic waste and biogas was collected at steady state conditions in order to obtain representative $\mathrm{CH}_{4}$ and $\mathrm{CO}_{2}$ content. For the fermentation tests, the biogas was recirculated into the bioreactors to enhance the mass transfer rate of gaseous $\mathrm{CO}_{2}$ in fermentation broth. The flow of biogas 
to the reactors was provided by peristaltic pumps at a pressure of 1.3-1.4 bar. The temperature and $\mathrm{pH}$ were fixed at $37^{\circ} \mathrm{C}$ and 6.7 , respectively. The latter was done by adding $\mathrm{NaOH}(8 \mathrm{M})$ automatically to the fermentation broth. Besides the samples from fermentation broth, gas samples ( $\sim .2 \mathrm{~mL})$ were taken from reactor headspace for $\mathrm{CO}_{2}-\mathrm{CH}_{4}$ composition analysis.

\subsection{Analytical methods}

Cell growth was monitored measuring the optical density at $660 \mathrm{~nm}\left(\mathrm{OD}_{660}\right)$ using a spectrophotometer (Jenway Buch and HolmA/S 64050UV/vis, United Kingdom) after carbonate salt removal by mixing the sample with $7 \%(\mathrm{w} / \mathrm{v}) \mathrm{HCl}$ at the ratio of $1: 4$. At $\mathrm{OD}_{660}$ of 1.0, B. succiniciproducens has a concentration of $0.2694 \mathrm{~g}$ dry cell weight (DCW)/L, A. succinogenes has the concentration of $0.626 \mathrm{DCW} / \mathrm{L}$ (data not shown). Glucose, succinic acid, lactic acid, formic acid, acetic acid, and ethanol were detected and quantified using high performance liquid chromatography (HPLC). The samples for HPLC were prepared by centrifuged at $13400 \mathrm{rpm}$ for $15 \mathrm{~min}$, the supernatants were diluted and filtered through $0.22 \mu \mathrm{m}$ syringe filter and stored at $-20^{\circ} \mathrm{C}$ until analysis. The HPLC (Agilent 1100 series) had a refractive index detector (detection of sugars, VFAs, and ethanol) and a Bio-Rad Aminex HPX-87H column ( $300 \mathrm{~mm} \times 7.8 \mathrm{~mm}$ ) with $5 \mathrm{mM} \mathrm{H}_{2} \mathrm{SO}_{4}$ as an eluent at a flow rate of $0.6 \mathrm{~mL} / \mathrm{min}$ with column oven temperature set to $55^{\circ} \mathrm{C}$. To protect the $\mathrm{HPX}-87 \mathrm{H}$ column from contamination and foreign particles a guard column was fitted to the system. The yield of succinic acid, expressed as a percentage, was defined as the amount of final succinic acid produced from 1 $\mathrm{g}$ of sugar consumed. The gaseous samples from bioreactor headspace were analyzed in gas chromatography (GC) using a TRACE 1310, Thermo Scientific with a TCD-detector and an HP-plot column. The concentration of $\mathrm{H}_{2} \mathrm{~S}$ in biogas was measured by portable gas analyzer Geotech Biogas 5000 .

Total solids (TS), volatile solids (VS), total Kjeldahl nitrogen (TKN), and total ammonia were measured according to APHA's Standard Methods [27]. Metal analysis of OFHKW was conducted performing microwave assisted wet digestion of $280 \mathrm{mg}$ of biomass with $\mathrm{HNO}_{3}, \mathrm{HCl}$ and $\mathrm{H}_{2} \mathrm{O}_{2}$ in closed vessels. Concentration of metals $\mathrm{P}, \mathrm{Ca}, \mathrm{Mg}, \mathrm{Na}, \mathrm{S}, \mathrm{K}, \mathrm{Fe}, \mathrm{Al}, \mathrm{Cr}, \mathrm{Mn}, \mathrm{Ni}, \mathrm{Cu}, \mathrm{Sr}$ and $\mathrm{Ba}$ was analyzed in a Vista-MPX 
inductively coupled plasma spectrometer with optical emission spectrometry, ICP-OES (Agilent, USA). Biochemical methane potential (BMP) which is the evaluation of amount of methane that can be produced during complete anaerobic digestion of biomass, was measured based on Angelidaki et al. [28], with organic loading of $2 \mathrm{gVS} / \mathrm{L}$ per day. The analysis run in triplicate glass reactors, with $80 \%$ of working volume as inoculum. The thermophilic inoculum was provided from the effluent of a well performing lab-scale reactor fed with cattle manure [29]. The batch assays were flushed with $\mathrm{N}_{2}$ gas to ensure anaerobic conditions and subsequently, were placed in incubator at $55^{\circ} \mathrm{C}$. Gaseous samples of $0.2 \mathrm{~mL}$ were taken from reactor headspace and analyzed by gas chromatography to define the volumetric $\mathrm{CH}_{4}$ production.

\subsection{Calculation of parameters}

Fermentations were terminated when carbon source was consumed completely verified by $\mathrm{OD}_{660}$ unchanged over four consecutive samples. Final titer of all products was the concentration at the end of fermentation. The yield of each product was defined as ratio of the final amount of product to the initial amount of the substrate in the media. Statistics were performed using the Origin2018b software. ANOVA (Analysis of Variance) with a Least Significant Difference (LSD) was used to compare and define significant differences $(p<0.05)$ among the different samples.

Electron equivalent balance was calculated from elemental composition, considering the electron content of carbon $(\mathrm{C})$, hydrogen $(\mathrm{H})$, oxygen $(\mathrm{O})$, and nitrogen $(\mathrm{N})$ are $+4,+1,-2$, and -3 per mole (emol), respectively [30]. For these calculations, the general active biomass formula of $\mathrm{C}_{1} \mathrm{H}_{1.8} \mathrm{O}_{0.5} \mathrm{~N}_{0.2}$ was considered for the microbial cells.

\section{Results and Discussion}

\subsection{Characterization of the organic fraction of household kitchen waste (OFHKW)}

The characterization of OFHKW used in this study is presented in Table 1. High organic content (VS/TS ratio of 94.3\%) together with high nitrogen content validates OFHKW as a nutrient-rich substrate for 
succinogenic bacteria. Furthermore, based on TKN and ammonia nitrogen, the protein content was calculated to be $132.2 \mathrm{~g} / \mathrm{kgVS}$ which is in agreement with the protein content of food and bakery wastes [31]. Metal analysis also verifies the presence of essential elements for microbial growth in OFHKW and negligible content of heavy metals that can inhibit the fermentation.

(Table 1)

The Biochemical methane potential (BMP) of OFHKW was achieved after 7 days of digestion, using thermophilic inoculum provided from the effluent of a well performing lab-scale reactor fed with cattle manure, with $405.1 \pm 18.7 \mathrm{~mL}_{\mathrm{CH} 4} / \mathrm{g}_{\mathrm{Vs}}\left(283.4 \pm 6 \mathrm{~mL}_{\mathrm{CH}} / \mathrm{g}_{\mathrm{COD}}\right)$. No lag phase was detected and the substrate showed relatively high biodegradability (81\%) compared to the theoretical value. However, considering that the price of succinic acid is much more than biogas, the valorization of organic content of OFHKW for succinic acid production seems more profitable rather than digesting it anaerobically in biogas plants. A detailed economic analysis taking into consideration costs for media cultivation and equipment will be helpful to claim the profitability of the two processes.

\subsection{Enzymatic hydrolysis}

In order to get monomeric sugars that are fermentable for succinogenic bacteria $A$. succinogenes and $B$. succiniciproducens, OFHKW was hydrolyzed enzymatically using cellulase (Celluclast $1.5 \mathrm{~L}^{\circledR}$ ) and cellobiase enzymes. The endoglucanases Celluclast $1.5 \mathrm{~L}^{\circledR}$ can break internal glucosidic linkages, while cellobiase or $\beta$ glucosidase has synergistic act on cellulase and hydrolyzes cellobiose into glucose. To find the appropriate amount of substrate and enzymatic loading, a series of hydrolysis experiments were run for $24 \mathrm{~h}$, with results summarized in Table 2. The time duration of $24 \mathrm{~h}$ for enzymatic hydrolysis was similar to hydrolysis of bakery waste [32] and food waste [33] reported elsewhere. A closer look in data of Table 2 indicates that almost for all substrate loading values, the obtained sugar amount increases between $20 \mathrm{U} / \mathrm{g}_{\mathrm{DM}}$ to $40 \mathrm{U} / \mathrm{g}_{\mathrm{DM}}$ enzymatic loading, which shows that $20 \mathrm{U} / \mathrm{g}_{\mathrm{DM}}$ enzyme is insufficient to release all the sugars in the substrate. However further increase in enzymatic loading from 40 to $50 \mathrm{U} / \mathrm{g}_{\mathrm{DM}}$ has almost no effect on total 
sugar concentration. This shows that the catalytic activity of the enzyme reaches its highest value at 40 $\mathrm{U} / \mathrm{g}_{\mathrm{DM}}$ and gets saturated afterwards. Also the results for enzymatic loading of 40 and $50 \mathrm{U} / \mathrm{g}_{\mathrm{DM}}$ shows that with increasing the substrate loading value, the sugar content changes linearly. This linear change is depicted in Figure 1 . This also clarifies that at 40 and $50 \mathrm{U} / \mathrm{g}_{\mathrm{DM}}$ of enzyme, the substrate loading is the only limiting factor of reaction. In the case of $20 \mathrm{U} / \mathrm{g}_{\mathrm{DM}}$, the low sugar content is not due to lower activity of enzyme, but is probably contributed to insufficient time of hydrolysis (24 h). However, longer time duration of enzymatic hydrolysis would indeed decrease the productivity $(\mathrm{g} / \mathrm{L} / \mathrm{h})$.

Also the final sugar content shows that the product of enzymatic hydrolysis is rich enough in nutrients for subsequent fermentation process, as nutrient requirements of media for succinogenic bacteria is considered to contain $30-70 \mathrm{~g} / \mathrm{L}$ glucose [34]. Furthermore as seen in Table 2, the highest sugar concentration of $150.3 \pm 2.4 \mathrm{~g} / \mathrm{L}$ for run 12 was achieved at high substrate loading of $20 \%(\mathrm{w} / \mathrm{v})$ with 50 $\mathrm{U} / \mathrm{g}_{\mathrm{DM}}$ of Celluclast $1.5 \mathrm{~L}^{\circledast}$. However, this amount of released sugar is only $26 \%$ higher than run 10 , with similar substrate loading but with $20 \mathrm{U} / \mathrm{g}_{\mathrm{DM}}$ of Celluclast $1.5 \mathrm{~L}^{\circledast}$. Due to the high cost of enzyme, the selected condition for enzymatic hydrolysis was decided to be run 10 , with substrate loading of $20 \%(w / v)$, $20 \mathrm{U} / \mathrm{g}_{\mathrm{DM}}$ of Celluclast $1.5 \mathrm{~L}^{\circledast}$ and $10 \mathrm{U} / \mathrm{g}_{\mathrm{DM}}$ of cellobiase. Also, the sugar analysis of enzymatic hydrolysis products shows that the majority of released sugar is in type of glucose rather than xylose, as OFHKW waste was more abundant in food waste than lignocellulosic materials. Furthermore, the glucose concentration used in fermentation media is a crucial parameter which determines the performance of succinogenic bacteria [35]. A comparison of the hydrolysis reaction performance in current study with other methods used for SA microbial production is summarized in Table 3. Finally, to get sufficient amount of hydrolysate for succinic acid production run 10 was up-scaled to $3.0 \mathrm{~L}$ in two bioreactors.

(Table 2)

(Table 3) 


\subsection{Glucose inhibition tests}

Due to source separation of OFHKW, this waste was mainly consisted of food residues, which after enzymatic hydrolysis were broken down to mainly glucose and xylose, $101.7 \pm 1.7$ and $17.6 \pm 0.0 \mathrm{~g} / \mathrm{L}$, respectively (Table 2$)$. The high content of glucose in the hydrolysate $(85 \% \mathrm{w} / \mathrm{w})$, and the reported inhibitory effect of glucose on A. succinogenes [35] underlined the need for elucidation of the effect of glucose on B. succiniciproducens used in current study. This data is needed for potential optimization of the SA yield based on sugar fermentation by B. succiniciproducens.

To study the effect of substrate inhibition on growth and SA production performance of $B$. succiniciproducens, batch fermentations were carried out at different initial glucose concentrations $\left(\mathrm{C}_{\mathrm{Glu}, 0}\right)$, as shown in Figure 2. It was observed that for B. succiniciproducens, the final titer of all products showed a similar increasing trend with increasing initial glucose concentration $\left(\mathrm{C}_{\mathrm{Glu}, 0}\right)$ with the highest value corresponding to $36.0 \pm 0.5 \mathrm{~g} / \mathrm{L}$ of succinic acid at $110 \mathrm{~g} / \mathrm{L}$ (Figure $2 \mathrm{~A}$ ),. However, at $\mathrm{C}_{\mathrm{Glu}, 0}$ beyond $40 \mathrm{~g} / \mathrm{L}$, the amount of acetic and formic acid products decreased dramatically, to even zero at $60 \mathrm{~g} / \mathrm{L}$ while lactic acid production boosted. At $60 \mathrm{~g} / \mathrm{L}$ initial glucose concentration the product spectrum changed significantly with lactic acid produced roughly at the same titer as succinic acid (Figure 2A). This is also clear from Figure $2 \mathrm{~B}$, that at higher $\mathrm{C}_{\mathrm{Glu}, 0}$ the overall yields of succinic, acetic and formic acid produced by $B$.

succiniciproducens were decreasing, while lactic acid yields were increasing. However, the titer of products (in terms of $\mathrm{g} / \mathrm{L}$ or $\mathrm{mol} / \mathrm{L}$ ) or specific conversion yield are not indicating the substrate utilization for synthesis the specific products. Therefore, energy content of the two competing products of succinic acid and lactic acid, in terms of electron equivalent, facilitates a more precise comparison between the formed products. This is calculated and depicted in Figure $2 C \& D$. It can be seen from Figure $2 \mathrm{C}$ that with initial glucose energy content of 6.6 electron equivalent, equal energy is allocated to succinic and lactic acid. It is also clear that higher initial glucose energy content leads to increase in the energy content of lactic acid, with a slight decrease with that of succinic acid (Figure $2 \mathrm{C}$ ). This can be seen that at higher initial glucose 
concentrations, B. succiniciproducens cells increase the flux to lactic acid production pathway, shifting from succinic acid to succinic-lactic producing pathway. A similar shift from succinic acid-producer to lactic acidproducer was also observed in A. succinogenes $130 \mathrm{z}$ with oxygen introduction to the fermentation broth, that resulted in shift in the carbon flux from C4 branch (with SA as main product) to C3 branch (with lactic acid as the abundant product) [36]. To investigate if the observed shift in product spectrum of $B$. succiniciproducens had any relevance to oxygen presence, the batch fermentation experiments with $\mathrm{C}_{\mathrm{Glu}, 0}=60 \mathrm{~g} / \mathrm{L}$ were repeated with two different reducing agents of $\mathrm{L}$-cycteine and $\mathrm{Na}_{2} \mathrm{~S} .9 \mathrm{H}_{2} \mathrm{O}$, but no meaningful change in succinic acid and lactic acid relative production was observed (data not shown here). This implies that the change in product spectrum is probably triggered for regulating intercellular metabolites to cope with environmental stress imposed by high substrate concentration.

(Figure 2)

The abovementioned change in the product spectrum of $B$. succiniciproducens is in agreement with the results of Becker et al. [25], who genetically modified B. succiniciproducens cells with deleting pyruvateformic acid lyase $(p / f D)$. The constructed strain had no formic acid production together with $80 \%$ reduction in acetic acid/ethanol. However, this modification caused the strains to enhance lactic acid production by 15 times. By calculating the stoichiometric coefficients for overall production reactions for succinic acid, lactic acid, and acetic acid/formic acid shown in Table 4, it is clear that the substrate-inhibited cells of $B$. succiniciproducens are not in need for high energy supply, as lactic acid pathway produces only 1 ATP compared to 3 ATPs of acetic acid/formic acid pathway [22].

(Table 4)

The results so far indicate that fermentation process using $B$. succiniciproducens at higher $\mathrm{C}_{\mathrm{Glu}, 0}$ dedicates more energy (in terms of equivalent electron) to lactic acid production, while the energy content of glucose allocated to succinic acid shows a slight decrease (Figure 2C). However, when the energy content of 
products (sum of succinic, lactic, acetic and formic acids) in several batches with increasing $\mathrm{C}_{\mathrm{Glu}, 0}$ were plotted and fitted against the energy content of substrate, Figure 2D, it was found that the cells allocate a relatively constant value of $54 \%$ of the total energy to product synthesis. In other words, regardless of $\mathrm{C}_{\mathrm{Glu}, 0}$, the cells use $54 \%$ of gained energy from glucose (in terms of equivalent electrons) to synthesize and secrete the products. This means that $\mathrm{C}_{\mathrm{Glu}, 0}$, only influences types of byproducts that are secreted by $B$. succiniciproducens cells, and the cells allocate equal portion of gained energy to products, regardless of what kind it is. However, with an objective on SA production, lower $\mathrm{C}_{\mathrm{Glu}, 0}$ are more desired.

Besides its effect on product spectrum of $B$. succiniciproducens, $\mathrm{C}_{\mathrm{Glu}, 0}$ also influences the time duration needed to utilize glucose and product synthesis (productivity). A typical fermentation at $\mathrm{C}_{\mathrm{Glu}, 0}=5$ and $60 \mathrm{~g} / \mathrm{L}$ is depicted in Figure $3 \mathrm{~A}$ and $\mathrm{B}$, respectively. As it is clear, at $\mathrm{C}_{\mathrm{Glu}, 0}$ higher than $60 \mathrm{~g} / \mathrm{L}$, the lag phase is longer, approximately $20 \mathrm{~h}$, which is probably time needed to acclimatize to the high substrate concentrations. Meanwhile the lag phase is almost zero at $\mathrm{C}_{\mathrm{Glu}, 0}=5 \mathrm{~g} / \mathrm{L}$. This longer lag phase influence adversely the rate of succinic acid production; which is higher at lower $C_{G l u, 0}$. It was observed that up to $C_{G l u, 0}=40 \mathrm{~g} / \mathrm{L}$, at which point the maximum SA production rate of $0.56 \pm 0.01 \mathrm{~g} / \mathrm{L} / \mathrm{h}$ was achieved. At $\mathrm{C}_{\mathrm{Glu}, 0}=60 \mathrm{~g} / \mathrm{L}$, the $\mathrm{SA}$ production rate falls to $0.28 \pm 0.01 \mathrm{~g} / \mathrm{L} / \mathrm{h}$ which is almost half of that of $C_{\mathrm{Glu}, 0}=40 \mathrm{~g} / \mathrm{L}$.

(Figure 3)

As mentioned in section 3.3, fermentation using B. succiniciproducens with initial glucose concentrations lower than $60 \mathrm{~g} / \mathrm{L}$ is more efficient in terms of SA yield and production rate. Based on this, fermentation in serum bottles using different concentrations of hydrolysate to provide sugar concentrations of $17,25,35$, and $60 \mathrm{~g} / \mathrm{L}$ was conducted using the two strains $A$. succinogenes and $B$. succiniciproducens. The final titers of products illustrated in Figure $4 A \& B$, shows that higher initial sugar concentration leads to higher production of all organic acids, with comparable maximum succinic acid titer at $60 \mathrm{~g} / \mathrm{L}$ of sugar of $21.1 \pm 3.5$ $\mathrm{g} / \mathrm{L}$ and $17.9 \pm 0.43 \mathrm{~g} / \mathrm{L}$ for $A$. succinogenes and $B$. succiniciproducens, respectively. At this sugar concentration of $60 \mathrm{~g} / \mathrm{L}$, comparing the molar ratio of products (SA: LA: FA: AA) for fermentation with $A$. 
succinogenes (0.56: 0.05: 0.08: 0.32) and B. succiniciproducens (0.5: 0.25: 0.07: 0.2) it makes it apparent that the latter allocates 5 times more energy on lactic acid than $A$. succinogenes. Also at lower sugar concentrations ( $17 \mathrm{~g} / \mathrm{L}$ and $25 \mathrm{~g} / \mathrm{L}$ ), the final titer of succinic acid produced by $B$. succiniciproducens exceeds that of $A$. succinogenes. At sugar concentration of $17 \mathrm{~g} / \mathrm{L}$, the energy content in terms of electron equivalent of products (SA: LA: FA: AA) for B. succiniciproducens is $(0.56: 0.09: 0.07: 0.3)$ is more promising than $A$. succinogenes $(0.5: 0.05: 0.1: 0.4)$, the energy content of $S A$ is higher, while that of byproducts is lower. In other words, at lower sugar concentration B. succiniciproducens seems to perform better than $A$. succinogenes with hydrolysate as the substrate, allocating more proportion of glucose to SA. By calculating succinic acid yield on consumed sugars ( $\left.g_{\mathrm{sA}} / \mathrm{g}_{\text {sugar }}\right)$ for the experiments, the highest yield of $0.46 \pm 0.0$ $\mathrm{g}_{\mathrm{s} A} / \mathrm{g}_{\mathrm{sugar}}$ is achieved at sugar concentration of $17 \mathrm{~g} / \mathrm{L}$ using $B$. succiniciproducens, compared to $0.33 \pm 0.0$ $\mathrm{g}_{\mathrm{s} A} / \mathrm{g}_{\mathrm{sugar}}$ for $A$. succinogenes. This led to the conclusion that lower sugar concentration of hydrolysate provides better performance and $B$. succiniciproducens converting sugars to mainly succinic acid. More interestingly, when fermentation results of $B$. succiniciproducens using almost similar sugar concentrations provided by hydrolysate and pure glucose were compared (Table 5), nearly similar results were obtained for succinic acid yield $\left(0.45 \mathrm{~g} / \mathrm{g}_{\text {sugar }}\right)$, which verifies that there is no inhibitors or growth-limiting compounds that might restrain the applicability of hydrolysate as substrate for SA production. The obtained fermentation results are also in good agreement with those reported in previous studies [37]. The higher titers and yields of hydrolysate compared to pure glucose is due to that $14.7 \%$ of the sugar content of hydrolysate is in the form of xylose, which has been shown to enhance organic acids production in $B$. succiniciproducens [22].

(Figure 4)

(Table 5) 


\subsection{Simultaneous succinic acid production and biogas upgrading}

Based on abovementioned results, final experiment of fermentation with real biogas as sole source of carbonate was conducted using hydrolysate at lowest sugar concentration in bioreactor (Figure 5B) together with similar experiment in serum bottle using $20 \mathrm{~g} / \mathrm{L}$ of $\mathrm{MgCO}_{3}$ as carbonate source (Figure $5 \mathrm{~A}$ ). The initial concentration measurement of $\mathrm{H}_{2} \mathrm{~S}$ in the supplying biogas was in the range of $1200-1600 \mathrm{ppm}$. It is widely accepted that soluble $\mathrm{H}_{2} \mathrm{~S}$ toxicity is a result of inhibition of metabolic activity in anaerobic bacteria, although the mechanisms is not fully understood. However, as the final $\mathrm{OD}_{660}$ obtained from bioreactor with biogas (Figure 5B) was similar to the serum bottles with $\mathrm{MgCO}_{3}$ (Figure $5 \mathrm{~A}$ ), $5.5 \pm 0.4$ and $5.6 \pm 0.3$, respectively, it can be concluded that the $\mathrm{H}_{2} \mathrm{~S}$ concentration had no inhibitory effect on the cell growth. As $\mathrm{H}_{2} \mathrm{~S}$ toxicity is the questioning point in real biogas application as carbonate source for SA production, these results are of high importance proving the applicability of this gas. Despite similar cell density of the two experiments, the final titer of $\mathrm{SA}$ produced from fermentation with $\mathrm{MgCO}_{3}$ was almost double the titer achieved from experiment using biogas, with $5.5 \pm 0.2 \mathrm{~g} / \mathrm{L}\left(0.39 \pm 0.0 \mathrm{gsA}_{\mathrm{s}} / \mathrm{g}_{\mathrm{glucose}}\right)$ and $3.8 \pm$ $0.8 \mathrm{~g} / \mathrm{L}(0.25 \pm 0.0 \mathrm{gsA} / \mathrm{gglucose})$, respectively. This variation in SA final titer and yield, as the initial sugar concentration for both microorganisms were similar, might be due to two reasons; first, the supplementation of $\mathrm{Mg}^{2+}$ ion in the media by $\mathrm{MgCO}_{3}$, which was also shown to increase the activity of phosphoenolpyruvate (PEP) carboxylase enzyme up to five times more [38]. As the pathway from PEP to oxaloacetate is directly related to succinate synthesis, higher $\mathrm{Mg}^{2+}$ concentration in fermentation broth results in enhanced titer of SA. Secondly, while carbonate concentration provided by biogas at 1.3-1.4 bar is not limiting for succinic acid production, but there is still higher available $\mathrm{CO}_{2}{ }^{2-}$ and $\mathrm{HCO}_{3}{ }^{-}$provided by 20 $\mathrm{g} / \mathrm{L}$ of $\mathrm{MgCO}_{3}$ in fermentation media. The concentration of carbonate is shown to be as a precursor for organic acids synthesis in cells and can dramatically influence the final titers [39]. However as the final titers of byproducts (lactic, formic and acetic acid) are approximately similar in fermentation with biogas and $\mathrm{MgCO}_{3}$ (Figure $5 \mathrm{~A}, \mathrm{~B}$ ), the difference in $\mathrm{SA}$ titer is most probably related to $\mathrm{Mg}^{2+}$ ion effect, as higher 
carbonate concentration in fermentation with $\mathrm{MgCO}_{3}$ should have resulted in higher titers of all organic acid, not just succinic acid.

(Figure 5)

Apart from final titer of $\mathrm{SA}$, another major difference in fermentation with $\mathrm{MgCO}_{3}$ and biogas as carbonate source was glucose consumption rate, with average value of $1.27 \pm 0.02$ and $2.22 \pm 0.25 \mathrm{~g}_{\mathrm{Glu}} / \mathrm{g}_{\mathrm{DCw}} . \mathrm{h}$, respectively. This difference in results shows approximately 2 times faster depletion of glucose as the main sugar provided by hydrolysate in bioreactor compared to serum bottle. Furthermore, considering the profile of $\mathrm{CH}_{4}-\mathrm{CO}_{2}$ composition change in biogas throughout the fermentation (Figure $5 \mathrm{C}$ ), $\mathrm{CO}_{2}$ consumption was ceased with sugar depletion in the reactor, with overall $8.0 \%(\mathrm{v} / \mathrm{v})$ reduction in biogas at the end of fermentation $(p<0.05)$. This leads to an increase in $4.7 \%(v / v)$ methane content of biogas in $8 \mathrm{~h}$ of fermentation with initial sugar content of $17 \mathrm{~g} / \mathrm{L}$ using $B$. succiniciproducens. Comparing these results with $31 \%(\mathrm{v} / \mathrm{v})$ methane upgrading in mock biogas composition by $A$. succinogenes with $32 \mathrm{~g} / \mathrm{L}$ initial glucose in $24 \mathrm{~h} \mathrm{[18],} \mathrm{the} \mathrm{results} \mathrm{are} \mathrm{still} \mathrm{promising} \mathrm{in} \mathrm{terms} \mathrm{of} \mathrm{time} \mathrm{duration} \mathrm{and} \mathrm{glucose} \mathrm{consumption} \mathrm{rate.} \mathrm{This}$ implies that supplementing more sugar concentration from hydrolysate into the fermentation broth to get higher cell density can enhance biogas upgrade and succinic acid production. However according to the results of substrate inhibition tests and fermentation in serum bottles (sections 3.3 and 3.4 ), it seems more efficient to provide the higher sugar content in gradual steps, rather than starting the fermentation process at high glucose concentration.

\section{Conclusions}

In this study for the first time hydrolysate of organic fraction of kitchen household waste was valorized to produce succinic acid with carbonate source provided in the form of salt and real biogas. This was accomplished by using two different bacteria, Actinobacillus succinogenes $130 \mathrm{z}$ and Basfia succiniciproducens and comparing their performance. Enzymatic hydrolysis of the waste resulted in total 
sugar content of $119.3 \pm 1.7 \mathrm{~g} / \mathrm{L}$ with $15 \%$ as xylose and $85 \%$ as glucose. However, substrate inhibition tests showed that supplying the fermentation media initially with this high sugar concentration can affect the SA production adversely. Hence, the fermentation of hydrolysate was carried out at low sugar concentration using the two microorganisms, supplying the carbonate in the form of salt and raw biogas. The fermentation of hydrolysate using B. succiniciproducens with $17 \mathrm{~g} / \mathrm{L}$ of sugar led to succinate production with a yield of $0.25 \pm 0.0 \mathrm{gsA}_{\mathrm{s}} / \mathrm{g}_{\mathrm{glucose}}$ and $8.0 \%(\mathrm{v} / \mathrm{v})$ of $\mathrm{CO}_{2}$ consumption in biogas. It is feasible to enhance biogas upgrading and succinic acid titer by supplying the reactor with more sugar, preferably in gradual steps, not to exceed glucose inhibitory concentrations in the reactor. As a proof of concept, this study shows the high potential of hydrolysate to be used for succinic acid production, with possibility of integration with real biogas upgrading.

\section{Acknowledgements}

The authors thank Julie Kathrine Lyager and Sofie Anthonisen for assistance with experimental works conducted in the study.

\section{Conflict of interest}

The authors declare no financial or commercial conflict of interest. 


\section{Figure Captions}

Figure 1: Linear change in sugar content of hydrolysate released at different substrate loading rates for enzymatic loading of $40 \mathrm{U} / \mathrm{g}_{\mathrm{DM}}$ (red) and $50 \mathrm{U} / \mathrm{g}_{\mathrm{DM}}$ (blue).

Figure 2: Substrate Inhibition tests with glucose for B. succiniciproducens; final titer $(\mathrm{g} / \mathrm{L})$ of products $(\mathrm{A})$, yield (g/g glucose) (B), the ratio of energy content of products to glucose (C), and sum of energy content of produced succinic and lactic acids (D).

Figure 3: Typical fermentation results of $B$. succiniciproducens using glucose as sole substrate with initial concentration of $5 \mathrm{~g} / \mathrm{L}(\mathrm{A})$ and $60 \mathrm{~g} / \mathrm{L}(\mathrm{B})$ versus time.

Figure 4: Fermentation results in serum bottles with $\mathrm{MgCO}_{3}$ as carbonate source at different sugar concentrations provided by hydrolysate, final product titers with $A$. succinogenes $(A)$ and $B$. succiniciproducens (B).

Figure 5: Fermentation profile of $B$. succiniciproducens with hydrolysate in serum bottle $(A)$ and bioreactor (B), with carbonate sources of $\mathrm{MgCO}_{3}$ and real biogas, respectively, with volumetric percentage change of biogas components along the fermentation (C). 


\section{References}

[1] Information got from: www.grandviewresearch.com/industry-analysis/bio-succinic-acid-market, (n.d.).

[2] E4tech, Re-Cord, Wur, From the Sugar Platform to biofuels and biochemicals, Final Rep. Eur. Comm. Dir. Energy. (2015) 183. doi:contract No. ENER/C2/423-2012/SI2.673791.

[3] J. a Wilsenach, M. Maurer, T. a Larsen, M.C.M. van Loosdrecht, From waste treatment to integrated resource management., Water Sci. Technol. 48 (2003) 1-9.

[4] FAO- Food and Agriculture Organization of the United Nations, Global food losses and food waste: extent, causes and prevention, in: SAVE FOOD!, 2011: p. 38. doi:10.1098/rstb.2010.0126.

[5] European Commission, T. Report, Preparatory Study on Food Waste Across Eu 27, 2010. doi:10.2779/85947.

[6] Å. Stenmark, C. Jensen, T. Quested, G. Moates, Estimates of European food waste levels, 2016. doi:10.13140/RG.2.1.4658.4721.

[7] T.H. Kwan, Y. Hu, C.S.K. Lin, Valorisation of food waste via fungal hydrolysis and lactic acid fermentation with Lactobacillus casei Shirota, Bioresour. Technol. 217 (2016) 129-136. doi:10.1016/j.biortech.2016.01.134.

[8] D. Pleissner, W.C. Lam, Z. Sun, C.S.K. Lin, Food waste as nutrient source in heterotrophic microalgae cultivation, Bioresour. Technol. 137 (2013) 139-146. doi:10.1016/j.biortech.2013.03.088.

[9] C. Nielsen, A. Rahman, A.U. Rehman, M.K. Walsh, C.D. Miller, Food waste conversion to microbial polyhydroxyalkanoates, Microb. Biotechnol. 10 (2017) 1338-1352. doi:10.1111/1751-7915.12776.

[10] M.S. Kim, J.G. Na, M.K. Lee, H. Ryu, Y.K. Chang, J.M. Triolo, Y.M. Yun, D.H. Kim, More value from food waste: Lactic acid and biogas recovery, Water Res. 96 (2016) 208-216. doi:10.1016/j.watres.2016.03.064.

[11] X. Yang, H. Wang, C. Li, C.S.K. Lin, Restoring of Glucose Metabolism of Engineered Yarrowia lipolytica for Succinic Acid Production via a Simple and Efficient Adaptive Evolution Strategy, J. Agric. Food Chem. 65 (2017). doi:10.1021/acs.jafc.7b00519.

[12] Y. Zeng, D. Bian, Y. Xie, X. Jiang, X. Li, P. Li, Y. Zhang, T. Xie, Utilization of food waste hydrolysate for microbial lipid and protein production by Rhodosporidium toruloides Y2, J. Chem. Technol. Biotechnol. (2016). doi:10.1002/jctb.5049.

[13] E. Uçkun Kiran, A.P. Trzcinski, W.J. Ng, Y. Liu, Bioconversion of food waste to energy: A review, Fuel. 134 (2014) 389-399. doi:10.1016/j.fuel.2014.05.074.

[14] M. Probst, J. Walde, T. Pümpel, A.O. Wagner, H. Insam, A closed loop for municipal organic solid waste by lactic acid fermentation, Bioresour. Technol. (2015). doi:10.1016/j.biortech.2014.10.034.

[15] G. Dreschke, M. Probst, A. Walter, T. Pümpel, J. Walde, H. Insam, Lactic acid and methane: Improved exploitation of biowaste potential, Bioresour. Technol. (2015). doi:10.1016/j.biortech.2014.10.136.

[16] N. Nghiem, S. Kleff, S. Schwegmann, Succinic Acid: Technology Development and Commercialization, 
Fermentation. (2017). doi:10.3390/fermentation3020026.

[17] E. Uçkun Kiran, A.P. Trzcinski, Y. Liu, Platform chemical production from food wastes using a biorefinery concept, J. Chem. Technol. Biotechnol. 90 (2015) 1364-1379. doi:10.1002/jctb.4551.

[18] I.B. Gunnarsson, M. Alvarado-Morales, I. Angelidaki, Utilization of $\mathrm{CO} 2$ fixating bacterium Actinobacillus succinogenes $130 Z$ for simultaneous biogas upgrading and biosuccinic acid production, Environ. Sci. Technol. 48 (2014) 12464-12468. doi:10.1021/es504000h.

[19] M. Jiang, J. Ma, M. Wu, R. Liu, L. Liang, F. Xin, W. Zhang, H. Jia, W. Dong, Progress of succinic acid production from renewable resources: Metabolic and fermentative strategies, Bioresour. Technol. 245 (2017) 1710-1717. doi:10.1016/j.biortech.2017.05.209.

[20] P. Kuhnert, E. Scholten, S. Haefner, D. Mayor, J. Frey, Basfia succiniciproducens gen. nov., sp. nov., a new member of the family Pasteurellaceae isolated from bovine rumen, Int. J. Syst. Evol. Microbiol. (2010). doi:10.1099/ijs.0.011809-0.

[21] J.J. Beauprez, M. De Mey, W.K. Soetaert, Microbial succinic acid production: Natural versus metabolic engineered producers, Process Biochem. (2010). doi:10.1016/j.procbio.2010.03.035.

[22] D. Salvachúa, H. Smith, P.C. St. John, A. Mohagheghi, D.J. Peterson, B.A. Black, N. Dowe, G.T. Beckham, Succinic acid production from lignocellulosic hydrolysate by Basfia succiniciproducens, Bioresour. Technol. 214 (2016) 558-566. doi:10.1016/j.biortech.2016.05.018.

[23] Københavns Kommune (2018). Spørgsmaal og svar om bioaffald. URL: https://www.kk.dk/artikel/spoergsmaal-og-svar-om-bioaffald, (n.d.).

[24] A.A. Modenbach, S.E. Nokes, Enzymatic hydrolysis of biomass at high-solids loadings-a review, Biomass Bioenerg. 56 (2013) 526-544. doi:10.1016/j.biombioe.2013.05.031.

[25] J. Becker, J. Reinefeld, R. Stellmacher, R. Schafer, A. Lange, H. Meyer, M. Lalk, O. Zelder, G. von Abendroth, H. Schr??der, S. Haefner, C. Wittmann, Systems-wide analysis and engineering of metabolic pathway fluxes in bio-succinate producing basfia succiniciproducens, Biotechnol. Bioeng. 110 (2013) 3013-3023. doi:10.1002/bit.24963.

[26] I.J. Oh, H.W. Lee, C.H. Park, S.Y. Lee, J. Lee, Succinic acid production from continuous fermentation process using Mannheimia succiniciproducens LPK7, J. Microbiol. Biotechnol. 18 (2008) 908-912.

[27] Standard Methods, STANDARD METHODS FOR THE EXAMINATION OF WATER AND WASTEWATER (11th ed.), Stand. Methods. (2005) 541. doi:10.2105/AJPH.51.6.940-a.

[28] I. Angelidaki, M. Alves, D. Bolzonella, L. Borzacconi, J.L. Campos, A.J. Guwy, S. Kalyuzhnyi, P. Jenicek, J.B. Van Lier, Defining the biomethane potential (BMP) of solid organic wastes and energy crops: A proposed protocol for batch assays, Water Sci. Technol. 59 (2009) 927-934. doi:10.2166/wst.2009.040.

[29] P. Tsapekos, P.G. Kougias, S. Kuthiala, I. Angelidaki, Co-digestion and model simulations of source separated municipal organic waste with cattle manure under batch and continuously stirred tank reactors, Energy Convers. Manag. 159 (2018) 1-6. doi:10.1016/j.enconman.2018.01.002.

[30] R. Heijnen, J.J.; Kleerebezem, Bioenergetics of microbial growth, Encycl. Ind. Biotechnol. Bioprocess, Biosep. Cell Technol. (2010) 1-24. doi:10.1002/0471250589.ebt026. 
[31] D. Pleissner, T.H. Kwan, C.S.K. Lin, Fungal hydrolysis in submerged fermentation for food waste treatment and fermentation feedstock preparation, Bioresour. Technol. 158 (2014) 48-54. doi:10.1016/j.biortech.2014.01.139.

[32] A.Y.Z. Zhang, Z. Sun, C.C.J. Leung, W. Han, K.Y. Lau, M. Li, C.S.K. Lin, Valorisation of bakery waste for succinic acid production, Green Chem. 15 (2013) 690-695. doi:10.1039/c2gc36518a.

[33] W. Han, D.N. Liu, Y.W. Shi, J.H. Tang, Y.F. Li, N.Q. Ren, Biohydrogen production from food waste hydrolysate using continuous mixed immobilized sludge reactors, Bioresour. Technol. 180 (2015) 54-58. doi:10.1016/j.biortech.2014.12.067.

[34] C.S.K. Lin, R. Luque, J.H. Clark, C. Webb, C. Du, Wheat-based biorefining strategy for fermentative production and chemical transformations of succinic acid, Biofuels, Bioprod. Biorefining. 6 (2012) 88-104. doi:10.1002/bbb.328.

[35] S.K.C. Lin, C. Du, A. Koutinas, R. Wang, C. Webb, Substrate and product inhibition kinetics in succinic acid production by Actinobacillus succinogenes, Biochem. Eng. J. 41 (2008) 128-135. doi:10.1016/j.bej.2008.03.013.

[36] Q. Li, D. Wang, Z. Song, W. Zhou, Y. Wu, J. Xing, Z. Su, Dual-phase fermentation enables Actinobacillus succinogenes $130 \mathrm{ZT}$ to be a potential role for high-level lactate production from the bioresource., Bioresour. Technol. 101 (2010) 7665-7. doi:10.1016/j.biortech.2010.04.058.

[37] H. Song, J.W. Lee, S. Choi, J.K. You, W.H. Hong, S.Y. Lee, Effects of Dissolved CO2 Levels on the Growth of Mannheimia succiniciproducens and Succinic Acid Production, Biotechnol. Bioeng. 98 (2007) 1296-1304. doi:10.1002/bit.21530.

[38] D. Wang, Q. Li, W. Li, J. Xing, Z. Su, Improvement of succinate production by overexpression of a cyanobacterial carbonic anhydrase in Escherichia coli, Enzyme Microb. Technol. 45 (2009) 491-497. doi:10.1016/j.enzmictec.2009.08.003.

[39] S. Lu, M.A. Eiteman, E. Altman, Effect of $\mathrm{CO} 2$ on succinate production in dual-phase Escherichia coli fermentations, J. Biotechnol. 143 (2009) 213-223. doi:10.1016/j.jbiotec.2009.07.012.

[40] C. Wang, X. Su, W. Sun, S. Zhou, J. Zheng, M. Zhang, M. Sun, J. Xue, X. Liu, J. Xing, S. Chen, Efficient production of succinic acid from herbal extraction residue hydrolysate, Bioresour. Technol. (2018). doi:10.1016/j.biortech.2018.06.041.

[41] Z. Sun, M. Li, Q. Qi, C. Gao, C.S.K. Lin, Mixed Food Waste as Renewable Feedstock in Succinic Acid Fermentation, Appl. Biochem. Biotechnol. (2014). doi:10.1007/s12010-014-1169-7. 


\section{Figures}

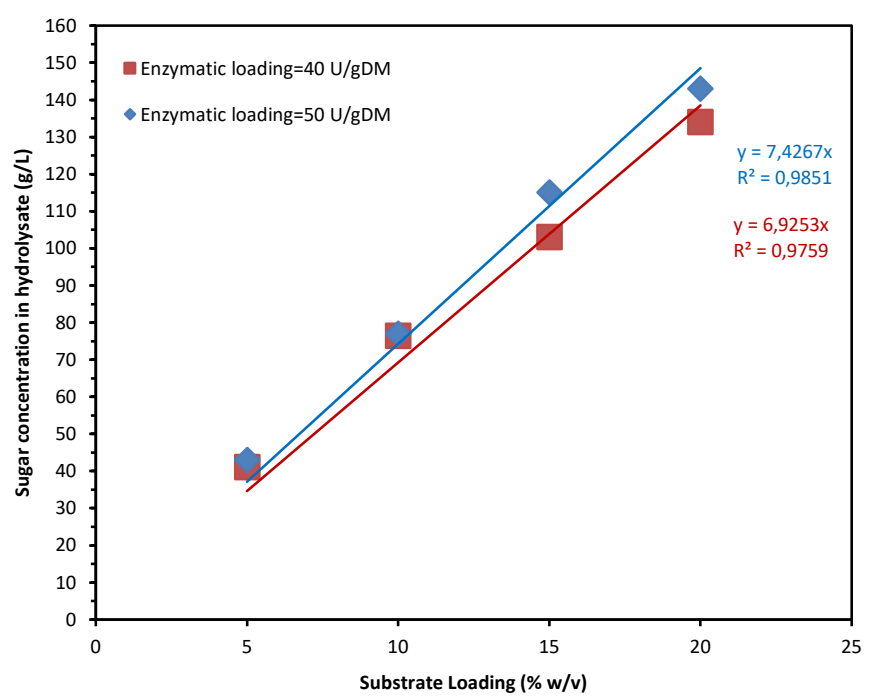

Figure 1 
A

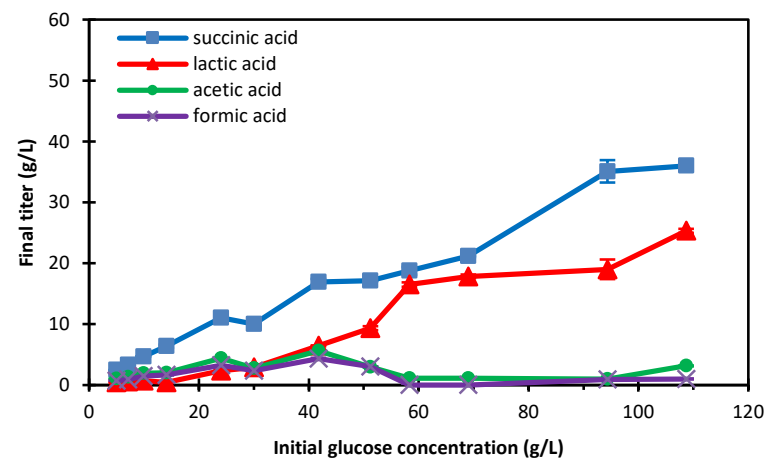

B

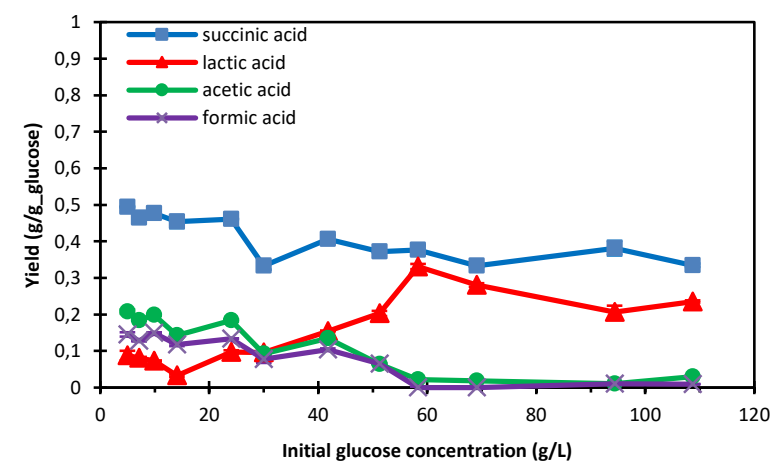

C

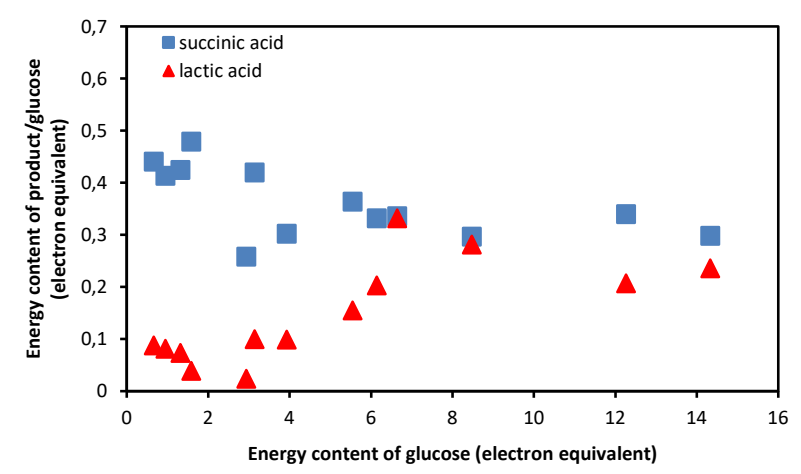

D

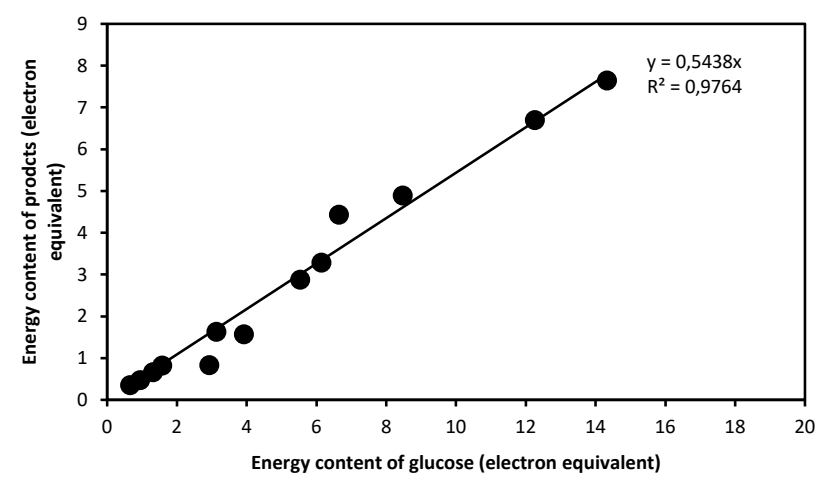

Figure 2 

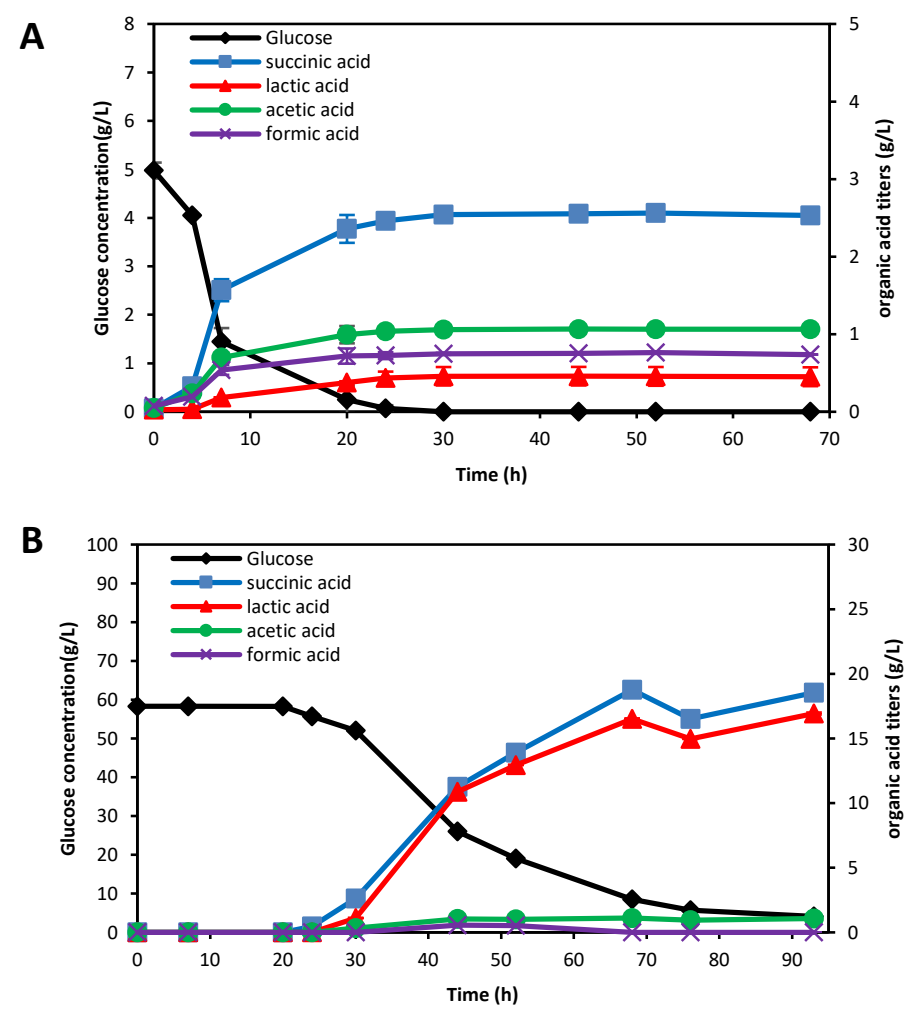

Figure 3 

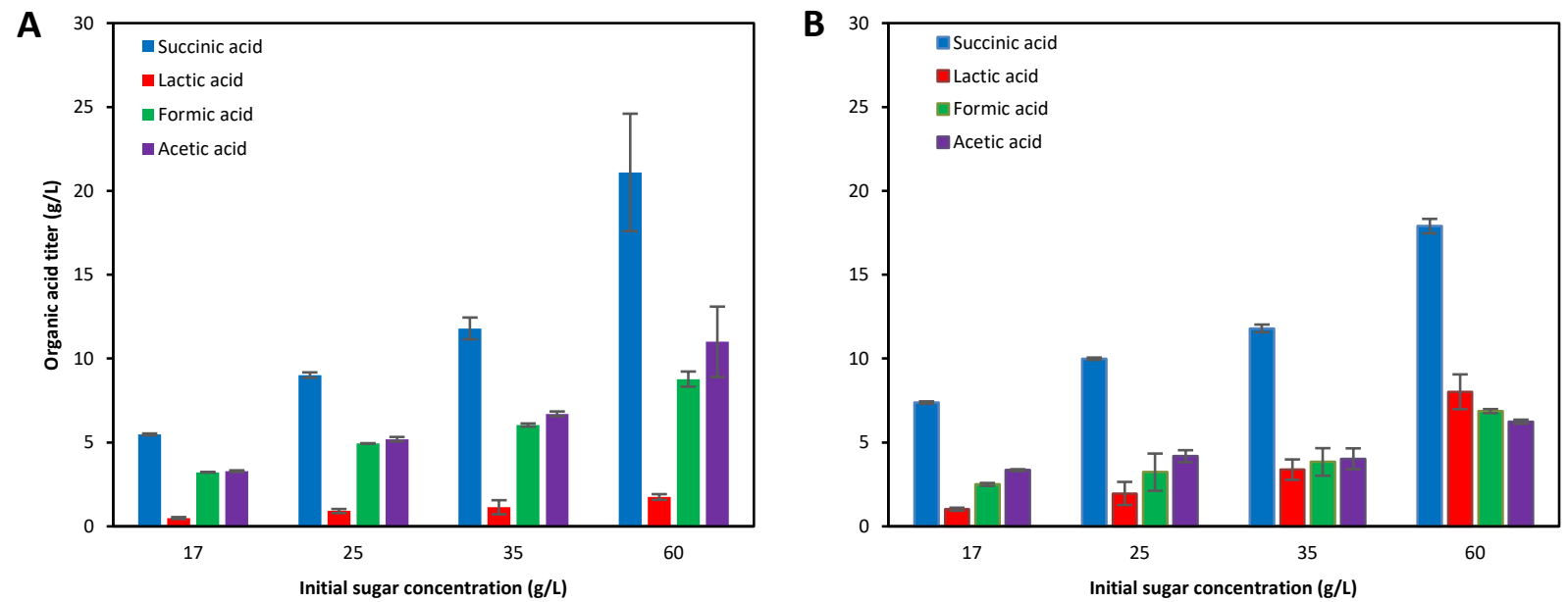

Figure 4 

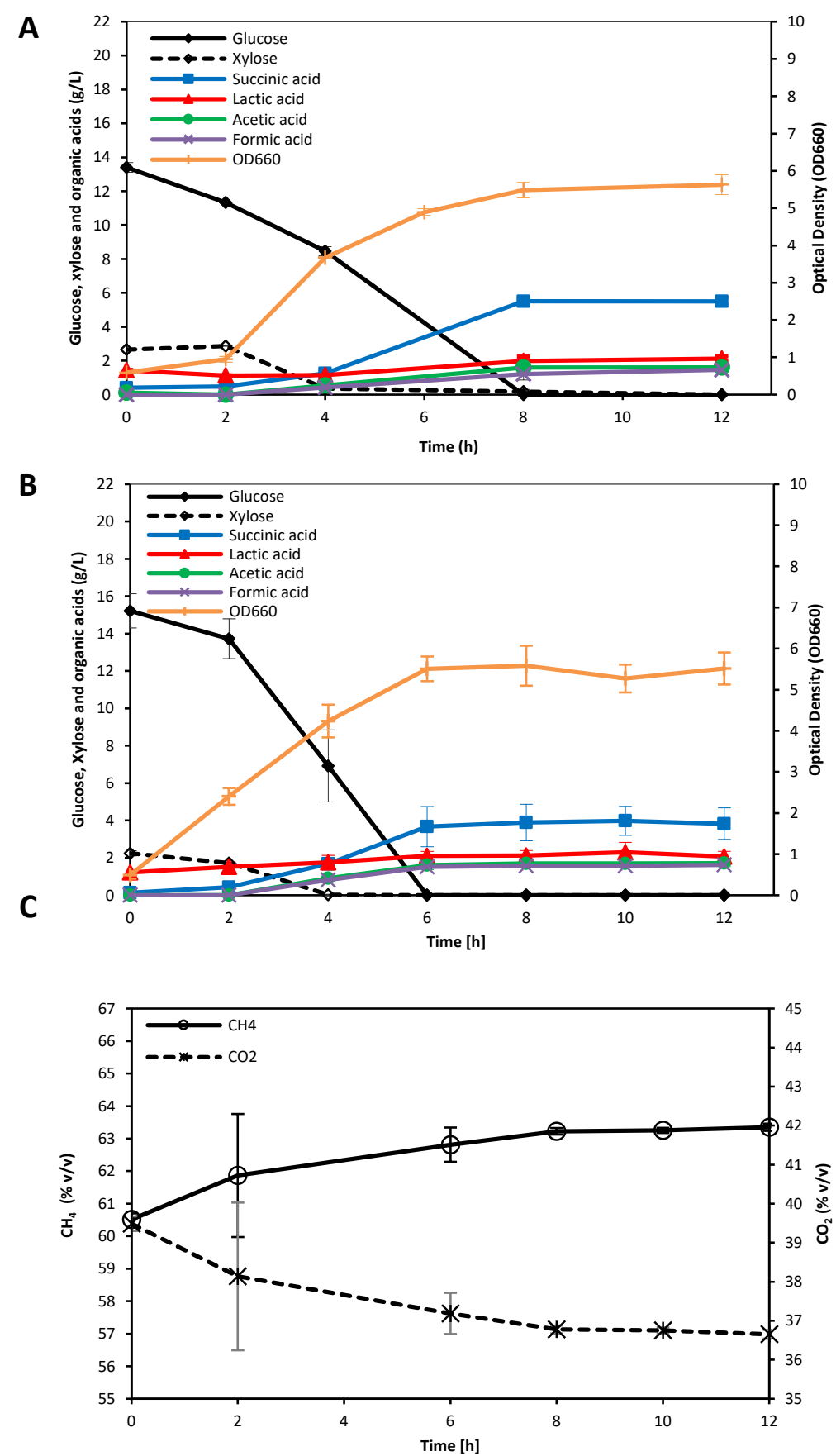

Figure 5 


\section{Tables}

Table 1: Characterization of OFHKW used in current study

\begin{tabular}{ll}
\hline Characterization & Value \\
\hline Total solid content (TS) & $976.4 \mathrm{~g} / \mathrm{kg}$ \\
Volatile solid content (VS) & $920.6 \mathrm{~g} / \mathrm{kg}$ \\
Chemical oxygen demand (COD) & $1316 \pm 32.0 \mathrm{~g} / \mathrm{kg}$ \\
Ammonia nitrogen & $4.05 \mathrm{~g} / \mathrm{kgVS}$ \\
Total Kjeldahl nitrogen (TKN) & $25.2 \mathrm{~g} / \mathrm{kgVS}$ \\
Protein content & $132.2 \mathrm{~g} / \mathrm{kgVS}$ \\
Metal analysis & \\
$\mathrm{P}$ & $3036.6 \pm 123.6 \mu \mathrm{g} / \mathrm{g}$ \\
$\mathrm{Ca}$ & $7869.2 \pm 416.0 \mu \mathrm{g} / \mathrm{g}$ \\
$\mathrm{Mg}$ & $1409.0 \pm 62.29 \mu \mathrm{g} / \mathrm{g}$ \\
$\mathrm{Na}$ & $4520.0 \pm 367.6 \mu \mathrm{g} / \mathrm{g}$ \\
$\mathrm{S}$ & $2102.1 \pm 129.9 \mu \mathrm{g} / \mathrm{g}$ \\
$\mathrm{K}$ & $5612.6 \pm 332.0 \mu \mathrm{g} / \mathrm{g}$ \\
$\mathrm{Fe}$ & $524.7 \pm 8.04 \mu \mathrm{g} / \mathrm{g}$ \\
$\mathrm{Al}$ & $48.04 \pm 54.8 \mu \mathrm{g} / \mathrm{g}$ \\
$\mathrm{Cr}$ & $0.298 \pm 0.058 \mu \mathrm{g} / \mathrm{g}$ \\
$\mathrm{Mn}$ & $20.925 \pm 2.063 \mu \mathrm{g} / \mathrm{g}$ \\
$\mathrm{Ni}$ & $1.245 \pm 0.001 \mu \mathrm{g} / \mathrm{g}$ \\
$\mathrm{Cu}$ & $2.895 \pm 0.07 \mu \mathrm{g} / \mathrm{g}$ \\
$\mathrm{Sr}$ & $27.329 \pm 14.37 \mu \mathrm{g} / \mathrm{g}$ \\
$\mathrm{Ba}$ & $2.83 \pm 1.24 \mu \mathrm{g} / \mathrm{g}$ \\
\hline
\end{tabular}


Table 2: Enzymatic hydrolysate of OFHKW at different substrate and enzymatic loadings.

\begin{tabular}{cccccccc}
\hline \multirow{2}{*}{ Run } & $\begin{array}{c}\text { Substrate } \\
\text { Loading }(\% \mathrm{w} / \mathrm{v})\end{array}$ & \multicolumn{2}{c}{ Enzymatic loading $\left(\mathrm{U} / \mathrm{g}_{\mathrm{DM}}\right)$} & \multicolumn{3}{c}{ Sugar concentration $(\mathrm{g} / \mathrm{L})$ in hydrolysate } \\
\cline { 3 - 7 } & & Celluclast $1.5 \mathrm{~L}^{\circledR}$ & Cellobiase & Glucose & Xylose & Arabinose & Total \\
\hline 1 & \multirow{2}{*}{5} & 40 & 10 & $41.4 \pm 0.7$ & 0 & $1.6 \pm 0.8$ & $43.1 \pm 1.5$ \\
2 & 50 & & $42.1 \pm 1.2$ & $1.1 \pm 0.6$ & $2.6 \pm 1.2$ & $45.9 \pm 1.6$ \\
\hline 3 & & 20 & & $54.6 \pm 6.3$ & $4.2 \pm 0.6$ & 0 & $58.9 \pm 1.2$ \\
4 & 10 & 40 & 10 & $73.0 \pm 9.4$ & $2.9 \pm 0.4$ & $1.6 \pm 0.7$ & $77.5 \pm 1.4$ \\
5 & & 50 & & $76.4 \pm 1.0$ & $5.8 \pm 0.2$ & $3.5 \pm 0.0$ & $85.7 \pm 1.2$ \\
\hline 6 & & 20 & & $86.7 \pm 1.5$ & 0 & 0 & $86.7 \pm 15$ \\
7 & 15 & 40 & 10 & $101.1 \pm 8.7$ & $8.1 \pm 1.6$ & $6.4 \pm 0.4$ & $115.7 \pm 10.7$ \\
8 & & 50 & & $103.7 \pm 7.6$ & $3.7 \pm 0.5$ & $2.8 \pm 0.2$ & $110.2 \pm 8.3$ \\
\hline 9 & & 20 & & $101.7 \pm 1.7$ & $17.6 \pm 0.0$ & 0 & $119.3 \pm 1.7$ \\
10 & 20 & 40 & 10 & $133.0 \pm 15$ & $13.3 \pm 0.0$ & 0 & $143 \pm 3.0$ \\
11 & & 50 & & $134.7 \pm 16.7$ & $5.14 \pm 0.7$ & $10.5 \pm 0.4$ & $150.3 \pm 2.4$ \\
\hline
\end{tabular}


Table 3: Comparison of performance of hydrolysis reaction in current study with other studies.

\begin{tabular}{|c|c|c|c|c|c|}
\hline $\begin{array}{l}\text { Hydrolysate } \\
\text { source }\end{array}$ & $\begin{array}{l}\text { Hydrolysis } \\
\text { method }\end{array}$ & $\begin{array}{l}\text { Total sugar } \\
\text { (g/L) }\end{array}$ & Advantages & Disadvantages & Ref \\
\hline Corn stover & $\begin{array}{l}\text { Deacetylation } \\
\& \text { dilute-acid }\end{array}$ & 138.2 & $\begin{array}{l}\text { Low-cost hydrolysis } \\
\text { method, high sugar content } \\
\text { of product, available source }\end{array}$ & $\begin{array}{l}\text { Extreme reaction condition for } \\
\text { hydrolysis, release of potential } \\
\text { inhibitors acetic acid and furfural }\end{array}$ & {$[22]$} \\
\hline $\begin{array}{l}\text { Herbal- } \\
\text { extraction } \\
\text { residues }\end{array}$ & $\begin{array}{l}\text { Dilute-acid \& } \\
\text { Enzymatic }\end{array}$ & 71.6 & $\begin{array}{l}\text { High sugar content of } \\
\text { product, available source }\end{array}$ & $\begin{array}{l}\text { High-cost hydrolysis method, Low } \\
\text { sugar content of product }\end{array}$ & [40] \\
\hline Food waste & $\begin{array}{l}\text { Fungal } \\
\text { autolysis and } \\
\text { hydrolysis } \\
\end{array}$ & 31.9 & $\begin{array}{l}\text { Low-cost hydrolysis } \\
\text { method, no inhibitors }\end{array}$ & $\begin{array}{l}\text { Requires to be collected manually } \\
\text { from restaurants; Low sugar } \\
\text { content of product }\end{array}$ & [41] \\
\hline Bakery waste & $\begin{array}{l}\text { Fungal } \\
\text { autolysis and } \\
\text { hydrolysis }\end{array}$ & 54.2 & $\begin{array}{l}\text { Low-cost hydrolysis } \\
\text { method, no inhibitors }\end{array}$ & $\begin{array}{l}\text { Requires to be collected manually } \\
\text { from source }\end{array}$ & [32] \\
\hline OFHKW & Enzymatic & 119.3 & $\begin{array}{l}\text { Available source, high sugar } \\
\text { content of product, no } \\
\text { inhibitors }\end{array}$ & High-cost hydrolysis method & $\begin{array}{l}\text { This } \\
\text { study }\end{array}$ \\
\hline
\end{tabular}


Table 4: Overall reactions for $B$. succiniciproducens using glucose as sole carbon source

\begin{tabular}{ll}
\hline Product & \multicolumn{1}{c}{ Overall reaction } \\
\hline Succinic acid & glucose $+2 \mathrm{CO}_{2}+2 \mathrm{NADH} \rightarrow 2$ succinic acid $+2 \mathrm{NAD}^{+}+$ATP \\
Lactic acid & glucose $\rightarrow 2$ lactic acid + ATP \\
Acetic acid/Formic acid & glucose $+2 \mathrm{NAD}^{+} \rightarrow 2$ acetic acid +2 formic acid +3 ATP $+2 \mathrm{NADH}$ \\
\hline
\end{tabular}


Table 5: Fermentation results of $B$. succiniciproducens in serum bottles with pure glucose and hydrolysate as substrate.

\begin{tabular}{lcc}
\hline Fermentation results & Glucose $(14 \mathrm{~g} / \mathrm{L})$ & hydrolysate $(17 \mathrm{~g} / \mathrm{L})$ \\
\hline Final titers $(\mathrm{g} / \mathrm{L})$ & & \\
\hline Succinic acid & $6.38 \pm 0.25$ & $7.38 \pm 0.07$ \\
Lactic acid & $0.46 \pm 0.05$ & $1.02 \pm 0.09$ \\
Formic acid & $1.65 \pm 0.05$ & $2.50 \pm 0.09$ \\
Acetic acid & $2.00 \pm 0.08$ & $3.35 \pm 0.06$ \\
Yield (g/g sugar) & & \\
\hline Succinic acid & $0.45 \pm 0.02$ & $0.46 \pm 0.00$ \\
Lactic acid & $0.03 \pm 0.00$ & $0.06 \pm 0.00$ \\
Formic acid & $0.12 \pm 0.00$ & $0.16 \pm 0.00$ \\
Acetic acid & $0.14 \pm 0.00$ & $0.21 \pm 0.00$ \\
\hline
\end{tabular}

